\title{
STUDIES OF THE PHYSIOLOGY, PHARMACOLOGY, AND BIOCHEMISTRY OF THE AUXINS ${ }^{1,2}$
}

\author{
By James Bonner and Robert S. Bandurski \\ Kerckhoff Biological Laboratories, California Institute of Technology, \\ Pasadena, California
}

\section{INTRODUCTION}

Several excellent reviews of auxin matters have appeared during the past few years dealing broadly with the subject as a whole, such as the Wisconsin Symposium on Plant Growth Substances which is referred to repeatedly below, as well as reviews of more restricted scope such as those of Thimann (116) and of the previous volumes in this series.

The present review need not, therefore, attempt to cover the entire spectrum of auxin physiology. It will concern a few aspects of the subject only, aspects in which particular progress has been made in recent years. It will attempt to evaluate the work which has been done in each of the several fields, to see in how far an integrated picture can be made of each and to make a few suggestions.

\section{Chemical Nature of Native Auxins}

That indoleacetic acid (IAA) is a principal native auxin of higher plants has been evident for some years (25). Not only has IAA been isolated in pure form from plant material [Haagen-Smit et al. (61)] but, in addition, the chemical and biological properties of concentrates of the active growth substance from a variety of plant tissues have been found to be similar to or identical with the properties of IAA. The widespread distribution of enzymatic systems for the synthesis of IAA from tryptophan and for the oxidative inactivation of IAA further indicate that this material is of natural occurrence. The principal question regarding the chemical nature of the native auxins at the present time appears to be the quantitative one of exactly what proportion of the total auxin of the plant is indeed IAA. Quantitative methods of auxin identification are needed to resolve this question.

The chemical identification of the native auxins has been difficult and uncertain in the past primarily because the auxin concentration in plant material is very low and a straightforward isolation of the active principle is in general impracticable. For this reason, indirect methods of identification have been used, particularly molecular weight by diffusion and kinetics of destruction in acid and alkaline solution. Both of these methods have now

${ }^{3}$ The preparation of this report was supported in part by the Hermann Frasch Foundation for Agricultural Chemistry.

2 The survey of the literature pertaining to this review was concluded in September, 1951. 
been shown to be unreliable. Thus, although IAA is the major component of the auxin of the oat coleoptile (141), the molecular weight as obtained by diffusion in crude extracts is too large by a factor of 50 to 100 per cent [Went (138); Wildman \& Bonner (141)]. Although pure IAA is rapidly destroyed by heating in $1 \mathrm{~N} \mathrm{HCL}$ in the presence of air, still IAA is protected from destruction in crude extracts or by the absence of oxygen or other oxidizing agents [Holley et al. (64)]. The native growth substance of cabbage leaves, now known to be principally IAA (64), is stable to heating in acid in crude extracts of cabbage leaves and for this reason was once held to be an auxin different from IAA [Link et al. (81)].

Several new and powerful methods are now available for the chemical characterization of a native plant growth substance even when only small quantities of the material are available. Of these methods, perhaps the most generally useful would appear to be paper chromatography, which might be used both for the isolation and the identification of growth substances. This technique has not yet, however, been applied to the problem on any considerable scale. Further indirect methods for the characterization of IAA are the riboflavin-sensitized photoinactivation of the material, which has been described and applied by Galston $(51,53)$, and the enzymatic destruction of IAA by IAA oxidase [Tang \& Bonner $(113,114)$; Wagenknecht \& Burris (135)]. A spectrophotometric micromethod has been developed (113, 141) which is sensitive to $1 \mu \mathrm{g}$. or less of IAA and which may be used alone or in conjunction with the procedures above. This method, which is based on the Salkowski reaction, depends on the formation by IAA of a red ferric complex in the presence of sulfuric (141) or perchloric (58) acid. It appears to be a valuable tool in the identification and estimation of plant growth substances if suitably and careffully applied. Thus, it may be used for the localization of IAA on chromatographic columns [Linser (82)] and papers [Stehsel (106)] or directly for comparison of the IAA content of a plant extract with the auxin content of the same extract as determined by biological assay [Wildmam \& Bonner (141)]. Certain materials, including indole, tryptophan, etc., interfere with the determination of IAA if they are present in high concentration. These substances are, however, ordinarily removed by a preliminary concentration of the growth substance fraction to include only ether-soluble organic acids. Certain derivatives of IAA also react with iron to form red complexes in acid solution. Such materials include indole acetamide, esters of IAA such as methylindole acetate, and possibly indole acetaldehyde. It would seem, however, that if these limitations are borne in mind, judicious application of the spectrophotometric assay to the purified organic acid extract of plant material may accomplish the satisfactory estimation of IAA content in many cases [Stehsel \& Wildman (107); Teas \& Newton (115)].

The chemical nature of the auxin of the oat coleoptile has been studied in some detail in the past and it has been shown that the extractable auxin of this organ is largely or entirely IAA [Wildman \& Bonner (141)]. In a new 
and extensive study of the subject, Reinert (101) was unable to find any evidence that the coleoptile contains a significant amount of any auxin other than IAA. This conclusion is based on the fact that the coleoptile auxin is completely destroyed by heating in acid, that it is destroyed by the IAA oxidase of pea with kinetics similar to the destruction of pure IAA, and that the activity-concentration relations in the oat curvature test are identical for coleoptile auxin and pure IAA. The major auxin component of the cabbage leaf behaves as IAA in. countercurrent distribution [Holley et al. (64)] and in chromatography [Linser (82)].

In at least three instances, the growth substance activity of a plant concentrate has been found to reside in part in materials not identical with IAA. In all of these instances, however, the material in question has turned out to be a derivative of or otherwise closely related to IAA. The first of these was the case of the neutral growth substance described by Larsen in 1944 (74). This is indole acetaldehyde and is active only after conversion in the plant to IAA (75). The second case is that of the fruit setting factor contained in immature corn kernels [Redeman et al. (98)]. This substance, which is some 100 times more effective than IAA itself, was shown by isolation to be the ethyl ester of IAA (98). Finally, in the countercurrent distribution of the acidic fraction of cabbage leaves, Holley et al. (64) found, in addition to IAA, two separable although minor components both active in the Avena curvature test. Although the chemical nature of these components was not resolved, it was shown in a qualitative way that both give the Salkowski reaction and are hence possibly related to IAA in some manner.

The formation of IAA from tryptophan in the higher plant, a reaction first noted by Wildman et al. (142) in 1946, involves the production of indole acetaldehyde as an intermediate. The final step in the formation of IAA consists, then, in the oxidation of this aldehyde to the corresponding acid, an oxidation which takes place readily both in vivo and in vitro with the oat coleoptile (75), leaves [Gordon \& Sanchez-Nieva (57)], and roots [Ashby (2)]. Ashby (2) and Larsen (76) have studied the specificity of this conversion and have shown that the enzyme system involved can attack $\alpha$-naphthylene acetaldehyde, converting it to the corresponding active growth substance, $\alpha$-naphthylene acetic acid. Similar results have been obtained with 2,4dichlorphenoxyacetaldehyde which is oxidized to an acidic growth substance, presumably 2,4-D, by extracts of oat coleoptile [Atkinson (3)]. The same interpretation is, no doubt, to be placed upon the work of Bentley (7) in which it is shown that the auxin activity of 2,3,6-trichlorbenzoic acid is equalled by the activity of 2,3,6-trichlorbenzaldehyde.

Although the final production of active growth substance from the corresponding aldehyde is then a relatively nonspecific oxidation, the tryptophan-IAA conversion as a whole shows a greater structural specificity. $\alpha$-Naphthylalanine, the naphthyl analog of tryptophan, is not, for example, converted to the corresponding growth substance (NAA) in the oat coleoptile (3). 


\section{Structure AND ACtivity}

An enormous amount of effort has been put into the synthesis and testing of auxin-like compounds and a very considerable number of materials have now been investigated for auxin activity. It is a matter for some concern, however, that the vast amount of information collected has not contributed materially to our understanding of the plant. The empirical rules relating structure to activity (71) have, of course, served to determine fruitful classes of compounds for further study and exceptions to the established rules (117; 139) have served to broaden and better define the concepts involved. Among the compounds synthesized and tested in the course of screening of structures related to the auxins, several compounds of great practical importance have been discovered. No broad new biological concepts have, however, resulted from this screening work nor have we attained any deeper insight into the mechanism of auxin action.

The exciting new attempt of Muir \& Hansch $(66,67,91,92)$ to utilize the vast mass of assorted facts concerning structure and activity to deepen our insight into auxin physiology is a particularly welcome one. Their investigations and their suggestions center primarily around a detailed study of the influence of nuclear substitution on the physiological activity of the phenoxyacetic, phenylacetic, and benzoic acids. Promotion of growth in the Avena section test (13) provides the basis for their assessment of physiological activity. It is well known that the slight auxin activity of phenoxyacetic acid can be greatly increased by the introduction of halogen substituents in to the ring. Thus, $m$ - and $p$-chlorophenoxyacetic acid are both active while 2,4-dichlorophenoxyacetic acid (2,4-D) is as active in the Avena section test as indoleacetic acid itself. Substitution of the aromatic ring by nucleophilic groups such as methyl does not augment the activity of phenoxyacetic acid as does substitution by the electrophilic halogen group. On the contrary, whereas the introduction of electrophilic groups into the para position increases activity, other characteristics of the molecule being suitable, the introduction of nucleophilic groups in the same position tends to decrease activity.

A striking correlation first formulated by Muir, Hansch \& Gallup (92) is that substitution of both the 2 and 6 position (both ortho positions) of phenoxyacetic acid renders the molecule inactive as a growth substance regardless of the other substituents. Thus, although 2,4-D is active, 2,6-dichlorophenoxyacetic acid and 2,4,6-trichlorophenoxyacetic acid are both inactive. One or both of the ortho positions may be blocked by a nucleophilic methyl group rather than by halogen. Thus, 2,4-D can be rendered inactive by introduction of either an electrophilic or a nucleophilic group in position 6 . Similar relations hold in the phenylacetic acids in which case, also, activity is dependent upon the presence of an unsubstituted ortho position. These observations are in general agreement with such scattered information as is available in the earlier literature $(112,144)$. That indoleacetic acid itself may require the presence of a free ortho group and that these may be the 2 and 4 positions 
of the indole nucleus is indicated by the fact that 2,4-di-substituted indoleacetic acids are totally inactive. Substitution in either the 2 or 4 position singly, as for example in the case of 2-methyl-or 2-ethylindole acetic acid, results in greatly reduced activity (66).

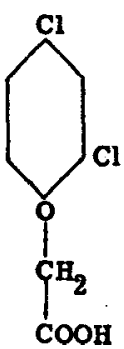

2, 4-Di-
chlorophen-
oxyacetic
acid
$\quad$ Active
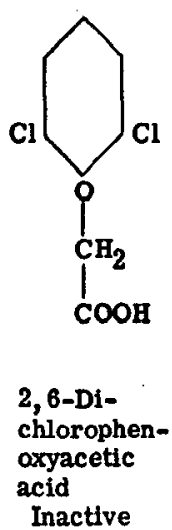
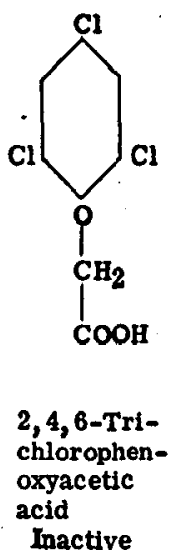
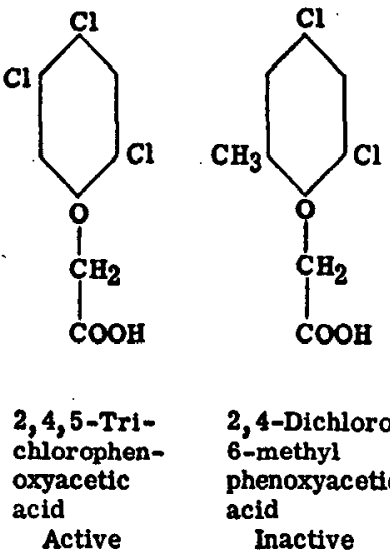

\section{2,4-Dichloro- \\ 6-methyl phenoxyacetic acid \\ Inactive}

On the basis of the observed importance of the ortho position to auxin activity, Muir, Hansch \& Gallup make the proposal that the basic reaction of an auxin within the cell involves two sites, the carboxyl group and an ortho group (92). As a working hypothesis Hansch, Muir \& Metzenberg (67) suggest that whereas the carboxyl group may become involved in a peptide or other amide type linkage, the ortho position may react with a sulfhydryl group such as the SH group of protein-bound cystiene. The nucleophilic-SH group of cysteine is known from animal experiments to substitute aromatic nuclei with the formation in animals of compounds of the aromatic nucleus-SR type (28). Although this is no more than a suggestion, it does possess attractive possibilities. The auxin mediated reaction is dependent on -SH groups present in the tissue as has been stressed by Thimann \& W. D. Bonner $(118,120)$. The auxin reaction is inhibited by reagents such as iodoacetate, arsenite, and $p$-chlormercuribenzoate $(118,120)$ or the unsaturated lactones which oxidize, combine with, or otherwise interfere with, -SH groups (133). The general concept of two point attachment of an auxin to its substratum appears also to permit of a more rigorous interpretation of the relation of cis-trans and other sterioisomers in relation to physiological activity than has heretofore been possible. The discovery of Bentley [(7); see also (147)] that 2,3,6-trichlorobenzoic acid is active as an auxin, even though both ortho positions are substituted, might superficially seem at variance with the concept of Muir \& Hansch. In fact, however, the detailed study of the substituted benzoic acids has made possible a searching test of the concept of the ortho position as an essential functional group of the auxin molecule. The rules which govern activity in the substituted benzoic acid series are different from the rules which apply to the phenoxyacetic and 
phenylacetic derivatives. Thus 2,4-dichlorobenzoic acid is totally inactive while the 2,6-dichloro compound is active $(66,137)$. 2-Chlorobenzoic acid is very slightly active, but this activity is increased by a second electrophilic group in either the meta or ortho position, in contrast to the phenoxy series where para substitution gives the greatest augmentation of activity. In summary, benzoic acids are inactive unless one or both ortho positions are substituted by an electronegative group such as halogen. This provides strong support for the view of Muir \& Hansch that substitution at the ortho position is involved in the auxin reaction, for in the benzoic acids the tendency to undergo ortho substitution is increased when electronegative

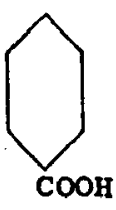

Benzoic
acid
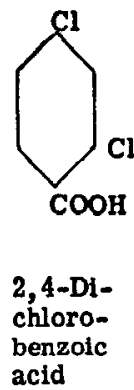

Inactive

Inactive
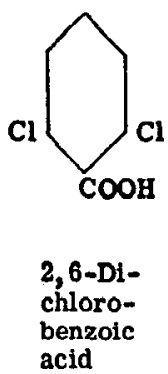

Active
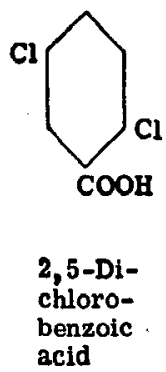

Active

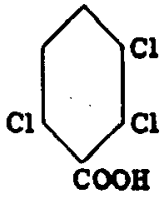

$2,3,6-$ Tri-
chloro-
benzoic
acid

Active

groups are originally present in the same position. This is to be contrasted to the state of affairs in the phenoxyacetic acids in which the tendency to undergo ortho substitution is decreased by the presence of electronegative groups at this position. The differences in reactivity of these two series of compounds lie in the proximity of the ortho position to the electron-attracting carboxyl group in the case of the benzoic acids, as contrasted to the proximity of the ortho position to the electron-rich phenoxy-linkage in phenoxyacetic acids. Our present body of empirical information concerning substitution and activity in the phenoxyacetic, phenylacetic, naphthalene acetic, naphthoxyacetic, and benzoic acids apparently can, in fact, be interpreted coherently in terms of a requirement for a critical electron density at those positions of the aromatic nucleus which are ortho to the side chain.

That the ortho position of the growth substance molecule does actually react with an appropriate nucleophilic group in vivo is indicated by the fact that during the course of the growth of Avena coleoptile sections in solutions of 2,6-dichlorobenzoic acid, inorganic chloride is liberated (67). Thus, in 8 hr. some 28 per cent of the chloride of the growth substance appeared as free chloride (67). This amount was greater than appeared when sections were incubated in an equal amount of the more readily hydrolized but physiologically inactive 2,4-dichlorobenzoic acid. Further study of this phenomenon should make it possible to identify the exact nature of the reactant involved and perhaps to discover the way in which auxins are bound in the plant. 
These investigations, then, point strongly to the ortho position as an important reactive site of the growth substance molecule. They suggest that auxins may react with their substrate or carrier molecules at two points, namely, the ortho position as well as the carboxyl group. The concept of the ortho position as a reactive site of the auxin molecule opens new approaches to the study of the native substrate of the growth substances.

\section{Auxin Antagonists and the Antiauxin Concept}

Certain compounds, which are inactive or essentially so as auxins, are nonetheless physiologically effective and elicit plant responses which result from inhibition of the action of auxin within the plant. Such antiauxin activity may be demonstrated in one of two general ways. In the first place, the growth or other responses induced by the application of auxin to a tissue low in native auxin may be shown to be depressed in the presence of nontoxic concentrations of the auxin antagonist. In the second place, the auxin antagonist may be applied to tissues or intact plants, which contain abundant native auxin. In this case, symptoms interpretable in terms of auxin deficiency may appear as, for example, lessened growth of the internodes and diminution of apical dominance. These criteria are not of themselves sufficient, of course, to establish a compound as an auxin antagonist. The crucial point is that the growth inhibition or other symptom induced be alleviated or abolished by the addition of further auxin.

The concept that the metabolism of a substrate may be blocked by a molecule of related structure, capable of reaction with the appropriate enzyme but incapable of metabolic transformation, was clearly recognized by Quastel (97) for the case of the inhibition of succinate oxidation by malonate. We say that malonate is a competitive inhibitor of the enzymatic oxidation of succinate. An auxin antagonist, a competitive inhibitor of the action of auxin, should, therefore, follow the general rules of competitive inhibition. Of these, the most important is that the extent of inhibition depends not on the absolute concentration of inhibitor but on the mole ratio between inhibitor and substrate in reaction mixture. The general principles which should govern growth inhibition by auxin antagonists are clearly developed in the early paper of Skoog, Schneider, \& Malan (103) which is concerned with $\gamma$-phenylbutyric acid and its interaction with indoleacetic acid (IAA) in the Avena test. $\gamma$-Phenylbutyric acid possesses a very slight activity in the Avena test (roughly 100,000 times less than that of IAA). The data of Figure 1 show that it is, however, active in inhibiting IAA induced curvature in the Avena test. For any given concentration of $\boldsymbol{\gamma}$-phenylbutyric acid, this inhibition is large at low auxin concentrations, small at high auxin concentrations. Avena coleoptile growth may, of course, be inhibited by other types of inhibitors. Figure 1 includes data on a typical inhibitor whose action is not related directly to auxin, namely, coumarin (132). Inhibition by a given concentration of this substance, an unsaturated lactone, is not decreased as auxin concentration is raised (19). Inhibition by 
by the unsaturated lactones involves the destruction of essential SH groups within the cell and is more or less competitive with SH-protecting substances such as BAL (2,3-dimercaptopropanol; Dimercaprol) [Thimann \& Bonner (121)].

It is proposed, then, that the term auxin antagonist be reserved for those materials whose effectiveness as auxin inhibitors depends on the inhibitor /auxin ratio. This use of the term would be consistent with the use generally applied in relation to metabolite antagonists. A further qualification should perhaps also be made, namely, that an auxin antagonist is a compound related in chemical structure to the auxins but possessed of the above-outlined
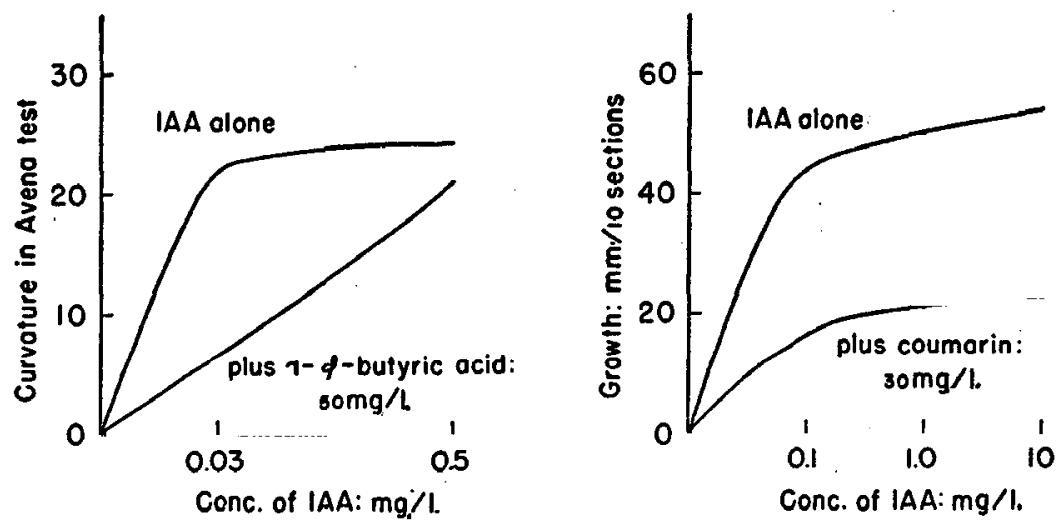

FIG. 1. Inhibition of auxin-induced growth responses by an auxin antagonist (left) and by a nonauxin related inhibitor (right). Left: Inhibition of Avena curvature test by $\gamma$-phenylbutyric acid, after Skoog et al. (103). Right: Inhibition of growth of Avena sections by coumarin, after Bonner (19).

physiological properties. With this qualification, the term auxin antagonist would appear today to comprise only compounds which are relatively specific to the inhibition of auxin activity and the auxin antagonist concept to be an experimentally useful one.

Demonstration that a particular substance acts as a competitor or antagonist to an auxin can be put on a more rigorous basis than is possible from the qualitative considerations outlined above through use of the kinetic analyses of Lineweaver \& Burk (80), Goldstein (55), and Strauss \& Goldstein (105). Treatment of the Avena test data of Skoog et al. (103) by these methods indicates that $\gamma$-phenylbutyric acid is a true competitive inhibitor of IAA in the Avena test.

The most thorough analysis to date of the action of an auxin antagonist is that of Van Overbeek, Blondeau \& Horne (130) which deals with transcinnamic acid. Trans-cinnamic acid is totally inactive as an auxin in contrast to the related cis-cinnamic acid which is active although less so than indoleacetic acid itself. Trans-cinnamic acid is active, however, in decreasing 
the growth response brought about by cis-cinnamic acid in the pea curvature or pea section test. The inhibition elicited depends not on the concentration

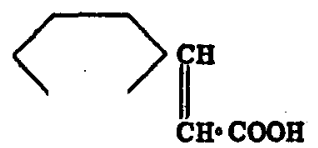

Trans-cinnamic acid

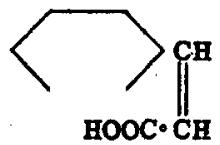

Cis-cinnamic acid

of inhibitor in the reaction mixture but on the ratio of inhibitor to growth substance. Thus, the addition of trans-cinnamic acid in a molecular ratio of 100 trans to 1 cis molecule brought about a 50 per cent reduction of the growth elicited by cis-cinnamic acid. Viewed in another way, the relative inhibitory effect of a given concentration of trans-cinnamic acid decreased as the concentration of cis-cinnamic acid in the reaction mixture increased.

Not only is trans-cinnamic acid active in antagonizing the growth effects of cis-cinnamic acid, but it is also active competitively against indoleacetic acid, naphthalene acetic acid, and 2,4-D. Approximately 1000 molecules of trans-cinnamic to one of active growth substance are, however, required to cause 50 per cent inhibition of an IAA-induced pea test curvature. Somewhat different mole ratios appear to be required for inhibition of the action of IAA, of naphthaleneacetic acid, and of 2,4-D in the pea section test. Of the auxin antagonists studied to date only trans-cinnamic acid is known with certainty as a natural product and in fact as a naturally occurring plant growth inhibitor [Bonner \& Galston (21)].

A second compound which possesses the ability to antagonize the growth promoting effects of auxin is 2,4-dichloranisole [Bonner (17)], a substance related to 2,4-D but lacking the terminal carboxyl group of the acetic acid side chain. Like inhibition by trans-cinnamic acid, dichloranisole inhibition depends on the molecular ratio between inhibitor and auxin. The ratio required for 50 per cent inhibition of Avena section growth (19) with 2,4-D as the auxin is approximately 20 molecules of inhibitor to 1 of auxin. Thus, dichloranisole (DCA) appears to be much more effective than trans-cinnamic acid as an auxin antagonist. Its slight solubility in water limits the concentration range over which it can be used. In addition, dichloranisole appears to act competitively only at low auxin levels and exerts a considerable nonspecific inhibition at higher auxin levels (19). These facts appear to exclude it from consideration as a general experimental tool.

Attention was first called to 2,3,5-triodobenzoic acid (TIBA) because of the morphogenetic effects which this material exerts on developing shoots (145). Galston (50) next noted that TIBA suppresses the activity of IAA in the Avena curvature test, and, in addition, inhibits both internode elongation and apical dominance in soybean. Unlike trans-cinnamic acid and DCA, TIBA itself possesses some slight growth activity $(91,119)$. That it is nevertheless effective in inhibiting the action of IAA in the Avena 
test has, however, been confirmed by several investigators $(91,119)$, the molecular ratio of inhibitor to auxin needed for 50 per cent inhibition varying from 8 to 34 in the several cases. Inhibitions caused by TIBA in the Avena or other growth tests have never been found to be fully reversible by added auxin and, in fact, according to de Waard \& Florshütz (44), if TIBA is added to the tissue $1 \mathrm{hr}$. before the application of auxin, the resulting inhibition is not reversible at all. This may indicate that in TIBA we are dealing with an antagonist which specifically but irreversibly combines with or otherwise destroys those sites in the cell which are essential to auxin action.

The action of $\gamma$-phenylbutyric acid, unlike that of TIBA, would appear to be wholly competitive, at least in the Avena test. The mole ratio of inhibitor to IAA needed for 50 per cent inhibition in the experiments of Skoog et al. (103) varies roughly between 350 and 600 . It is of interest to note that $\gamma$-phenylbutyric acid, like TIBA, is slightly active as an auxin in the Avena section test but, like TIBA, is an antagonist of other more active auxins. As Hitchcock \& Zimmerman (69) have so aptly expressed it in another connection, "In view of the remarkable growth regulating properties of TIBA $\ldots$, the question whether these regulators exhibit cell elongating activity in the Avena test is of minor importance. . .."

The relations of roots to auxin are somewhat different in general outline from those of stems and of Avena coleoptiles. Thus, roots are, by and large, inhibited in their growth by added auxin, although very low concentrations (in general, $10^{-8} M$ or less) may slightly increase root growth. Burström (29) has suggested in this connection that two histologically different and separable reactions may be involved in the responses of roots to applied auxin. The first of these, according to Burström, is the time interval between cell division in the meristem and initiation of cell elongation, an interval which Burström suggests may be shortened by low concentrations of auxin. The second auxin sensitive process in the root, according to Burström, is the rate of cell elongation, which appears to be decreased by added auxin. It is this latter process which is ordinarily dominant in studies of the effect of auxin on root growth. In any case, roots are inhibited in their growth by auxin concentrations above approximately $10^{-8} M$. Burström has now shown that certain substances related in structure to the auxins are not only ineffective in inhibiting root growth but actually increase root growth by a factor of two or more. This action may be reversed by auxin, the extent of the reversal depending on the auxin concentration. Of the materials discovered by Burström as active in increasing root elongation, the most interesting are auxin derivatives in which the acetic acid side chain is replaced by an isobutyric group. Thus, 4-chlorophenoxyisobutyric acid (29) and indole-3isobutyric acid (31) are both effective in increasing root growth when supplied at concentrations of $10^{-6}$ to $10^{-5} \mathrm{M}$. The mole ratio of 4-chlorophenoxyisobutyric acid to IAA needed for 50 per cent reduction of the growthstimulating effect is approximately 350 . Although the 4-chloro-substituted compound appears to be the most active of the phenoxyisobutyric acids 
tested by Burström, a variety of differently substituted compounds of this group are also more or less effective. Phenoxyisobutyric acid itself is active in increasing root growth as are its 2 - and 3-monochloro substituted derivatives (30). 2,4,-Dichloro, 2,4,5- and 2,4,6-trichloro, as well as 2,3,4,5,6pentachlorophenoxyisobutyric acid are all active. Thus, the ortho positions may both be blocked and the compound yet retain auxin antagonist activity.

The substituted phenoxyisobutyric acids are not only effective in increasing root growth, but also bring about other morphogenetic responses which suggest that they may function broadly as auxin antagonists (83). That effectiveness in increasing root growth is a good criterion for the screening of potential auxin antagonists is suggested not only from Burström's work, but also by the fact that during the course of an earlier search for an auxin antagonist (17) the substance 2,4-dichloranisole was selected for trial because of its reported activity in increasing the growth of corn roots (123). A variety of further substances related to the auxins in structure have been reported to be effective in increasing root growth and have been included in Table I, which presents a summary of information thus far available on materials which appear to possess auxin antagonist activity.

What can we now conclude as to the alterations in chemical structure which may transform a compound from an active auxin to an antiauxin? The following tentative proposals may be made on the basis of the information at hand:

(a) Molecules which are themselves weakly active as auxins may act antagonistically to molecules of more active compounds ( $\gamma$-phenylbutyric acid, possibly TIBA).

(b) Certain specific alterations of the side chain of an active compound may transform it into an antagonist. Such alterations include, for example, substitution of the isobutyric for the acetic side chain, elimination of the carboxyl group from the side chain (as in 2,4-dichloranisole), or isomerization (as in the case of trans-cinnamic acid). In so far as we can now judge, nuclear substitution and even the exact nature of the ring system involved is less important in determining auxin antagonist activity than it is in determination of auxin activity itself.

It is of interest to note that in several instances alteration of the active molecule by a single structural or configurational step may result not only in loss of auxin activity but in transformation of the molecule into an antiauxin. Thus, indole- $\alpha$-propionic acid is active (one optical isomer only) but introduction of two methyl groups at the alpha position results in a compound with antiauxin activity. It would quite evidently be of interest to examine for antiauxin activity other groups of auxin analogs which have been reported to be inactive as auxins.

Of what interest can the general subject of the antiauxins be to plant physiology and to agriculture? These materials hold promise both as research tools and as crop control agents. From the standpoint of auxin lore, the modest amount of work done with the auxin antagonists has already shown us that in general an antagonist to one active growth substance is an antago- 


\section{TABLE I}

A Summary of Investigations of Possible Auxin Antagonists

\begin{tabular}{|c|c|c|c|c|c|}
\hline Substance & $\begin{array}{c}\text { Antagonistic } \\
\text { to: }\end{array}$ & $\begin{array}{l}\text { Approx. } \\
\text { mole ratio } \\
\text { for } 50 \% \\
\text { inhibition }\end{array}$ & Test & $\begin{array}{l}\text { Extent of } \\
\text { reversal } \\
\text { by auxin }\end{array}$ & Author \\
\hline $\begin{array}{l}\text { 1. } \lambda \text {-Phenylbutyric } \\
\text { acid }\end{array}$ & IAA & 350 & Avena test & much & Skoog at al. (103) \\
\hline $\begin{array}{l}\text { 2. Trans-cinnamic } \\
\text { acid }\end{array}$ & $\begin{array}{l}\text { cis-cinnamic } \\
\text { IAA } \\
2,4-D \\
\text { NAA }\end{array}$ & $\begin{array}{r}100^{*} \\
10 \\
10,000 \\
1,000\end{array}$ & $\begin{array}{l}\text { pea section } \\
\text { pea section } \\
\text { pea section } \\
\text { pea section }\end{array}$ & $\begin{array}{l}\text { much } \\
\text { much } \\
\text { much } \\
\text { much }\end{array}$ & $\begin{array}{l}\text { Van Overbeek et al } \\
\quad(130)\end{array}$ \\
\hline 3. 2,4-Dichloroanisole & $\begin{array}{l}2,4-D \\
\text { IAA }\end{array}$ & 20 & $\begin{array}{l}\text { Avena sec- } \\
\text { tion }\end{array}$ & much & Bonner $(17,19)$ \\
\hline \multirow{3}{*}{$\begin{array}{l}\text { 4. } 2,3,5 \text {-Triodoben- } \\
\text { zoic acid }\end{array}$} & IAA & 8 & Avena test & - & Galston (50) \\
\hline & IAA & 26 & Avena test & little & $\begin{array}{l}\text { Thimann \& Bonner } \\
\text { (119) }\end{array}$ \\
\hline & IAA & 34 & Avena test & little & $\begin{array}{l}\text { de Waard \& Flor- } \\
\text { schütz (44) }\end{array}$ \\
\hline $\begin{array}{l}\text { 5. p-Chlorophenoxy } \\
\text { isobutyric acid }\end{array}$ & IAA & 300 & wheat root & much & Burström (29) \\
\hline $\begin{array}{l}\text { 6. Indole-3-isobutyric } \\
\text { acid }\end{array}$ & $\begin{array}{l}\text { native root } \\
\text { auxin }\end{array}$ & $\begin{array}{l}\text { approxi- } \\
\text { mately as } 5\end{array}$ & wheat root & - & Burström (31) \\
\hline $\begin{array}{l}\text { 7. 2,4-Dichlorophenyl } \\
\text { sulfone acetic acid }\end{array}$ & $\begin{array}{l}\text { native root } \\
\text { auxin }\end{array}$ & $\begin{array}{l}\text { less active } \\
\text { than } 5\end{array}$ & wheat root & - & $\begin{array}{l}\text { Wilske \& Burström } \\
\text { (143) }\end{array}$ \\
\hline $\begin{array}{l}\text { 8. (1 Naphthyl-methyl } \\
\text { sulfide) propionic } \\
\text { acid) }\end{array}$ & $\begin{array}{l}2,4-D \\
\text { NAA } \\
\text { IAA }\end{array}$ & $\begin{array}{l}100 \\
100\end{array}$ & flax root & $\begin{array}{l}\text { complete } \\
\text { complete } \\
\text { much }\end{array}$ & Aberg (1) \\
\hline
\end{tabular}

* Computed on basis of undissociated molecules only.

nist to many, perhaps to all. This would appear to strengthen the view that the action of such different types of substances as IAA and 2,4,-D is basically similar. From the research stand point also, the use of auxin antagonists may permit us to lower artificially the level of effective auxin in an otherwise normal plant and thus to identify more clearly the nature and extent of the processes which are auxin-controlled in the plant. Knowledge of the nature of action of antiauxins may well increase our understanding of the normal auxin economy of the plant. It becomes even more apparent that the effective auxin level in a living tissue is a resultant not only of the concentration of auxin itself in the tissue but also of a variety of naturally occurring inhibitors of auxin action. Some of these inhibitors are doubtless coumarins or coumarin derivatives; others may be actual auxin antagonists. From the standpoint of crop control, the development of an understanding of auxin antagonists and their use would appear to be a reasonable approach to the problems which are the converse of those which we now control by the application of 
auxins. Thus, when we want to make the fruit stay on the tree we apply an auxin. To make it drop off we might try an auxin antagonist.

\section{Auxins and Flowering}

It is now clear that flower initiation may be suppressed in several species by the application of auxins and that, contrariwise, flower initiation may be promoted under certain circumstances by the application of auxin antagonists. Our knowledge of the auxin relations of the flowering process is confined principally to results obtained from artificial application of active substances. It would appear to be quite possible, however, that flowering may normally be influenced or even controlled by fluctuations in the auxin economy of the plant.

A great number of plants of a great number of species have in the past been sprayed or otherwise treated with a wide variety of active growth substances. In only a small number of cases have any dramatic effects of auxins on flower initiation been recorded, and only in a still smaller number of instances has it been clearly shown that floral initiation has been suppressed by auxin aṕplication. This anomaly appears to result from at least two conditions which circumscribe the detection of auxin effects on flowering. In the first place, plants differ greatly in the ease with which flowering is inhibited by auxin application. In the second place, the inhibition of flowering appears to be best achieved by continued application of concentrations of growth substance well below those which are ordinarily given in experiments designed to influence growth in general and in which one or a few applications at most are made. Thus, in the light of our present knowledge, it is no occasion for surprise that effects on flowering have been observed in so few of the past experiments on auxin application to intact plants.

The first specific mention of the inhibition of floral initiation by applied auxin was by Dostal \& Hosek in 1937 who applied indoleacetic acid in lanolin paste to the leaves of ripe-to-flower shoots of Circaea (45). A similar clear inhibition of floral initiation by IAA, applied in lanolin paste, was achieved in 1938 by Hamner \& Bonner with Xanthium, a photoperiodically sensitive short-day plant (65). That flowering of the pineapple may be inhibited by applied growth substance was demonstrated by Cooper in 1942 (41). Cholodny in 1939 (35) and Galston in 1943 (48) both clearly formulated the view that high auxin levels in the plant may be unfavorable to flowering. Despite these early indications of a relation between auxin and flowering, interest in the subject did not become general until 1947, in which year the first systematic report of the inhibition of photoperiodic induction of Xanthium by auxin appeared (124). Indoleacetic acid, naphthalene acetic acid, and 2,4-D were all found to be effective in relatively low concentration if continuously applied $(24,124)$. That the inhibitory effect of auxin on flowering is exerted in the leaf was also indicated. Similar relations obtain in the inhibition of floral differentiation of the short-day plant Kalanchoe [Harder \& van Senden (68)]. Entirely similar, if less spectacular, effects of auxin in inhibition of flowering have been found for short-day teosinte [Leopold \& Thimann (77)]. 
Inhibition of flower formation in further short-day plants by periodic spraying with IAA or NAA has been reported by von Denffer \& Gründler (134), by Liverman (83), and by Lora (84). The inhibition of flowering of short-day plants by applied auxin occurs only when the auxin is supplied during the photoperiodic induction period and is ineffective if supplied immediately after the expiration of this period $(79,83)$. Auxin treatment not only prevents the expression of flowering in the treated plant, but it also prevents the synthesis in or export from the leaves of any flower-forming stimulus, since plants treated with auxin during the induction period are unable to induce flowering in untreated graft partners $(24,124)$. Inhibition of floral initiation does not result simply from a general grow th inhibition, since plants in which flowering is suppressed by auxin treatment continue normal vegetative development $(24,68)$.

The effects of auxin treatment on the flowering response of photoperiodically sensitive long-day plants are still somewhat obscure. Complete suppression of flowering with continued vegetative growth results from repeated auxin (daily spray) treatment of Calendula [von Denffer \& Gründler (134)]. In three further long-day species, flowering was merely retarded by IAA application, the retardation being largely unspecific in nature and consisting of a general delay in development. With Wintex barley, on the other hand, continuous application of low concentrations of auxin (IAA or NAA) may actually increase the number of floral primordia found [Leopold \& Thimann (77)].

We have little information on the influence of repeated or continuous auxin treatment on flowering of photoperiodically indeterminate plants. The data available suggest, however, that in this group, auxins so applied tend to delay or inhibit flowering. Thus, Laibach \& Kribben (73) achieved suppression of flowering of axillary shoots of Cucumis by application of NAA or IAA (in paste form) and vegetative growth continued in the shoots where flowering was suppressed. IAA applied to the root system delays flower initiation in petunia and soy bean [Green \& Fuller (60)]. Many of the reports concerning the effects of growth substance treatment on reproductive behavior of indeterminate plants have, however, been uncritical in that the appearance of flower buds rather than of floral primordia has been used as the criterion of reproductive response.

In summary, application of auxin retards or completely suppresses floral initiation in several short-day plants. The effect is exerted during the photoinductive period and appears to be exerted upon the leaves. Striking qualitative effects of auxin application to long-day and indeterminate plants have thus far been reported in only a few scattered cases. The responses which have been recorded include both the inhibition and the promotion of flowering. With short-day as well as with certain long-day and indeterminate plants, inhibition of floral initiation by auxin can be achieved in such a manner as to result in continued vegetative growth.

Just as floral initiation may be inhibited by applied auxin, floral initiation 
may be promoted by applied antiauxins, i.e. auxin antagonists. Perhaps the clearest instance of this relation is found in Xanthium. The cocklebur flowers only on a regime of short days and long nights. If the night is interrupted either by a light flash or by low-intensity light of longer duration, the plants remain vegetative (65). The application to Xanthium of a variety of auxin antagonists causes the plant to flower even when the photoperiodic regime is unsuitable so that control untreated plants remain vegetative. Thus, TIBA and DCA can overcome the effect of low-intensity supplementary light [Bonner (18)]. TIBA and a variety of other auxin antagonists are able to overcome the inhibitory effect of a light flash given in the center of a long, dark period (83). The effect of applied antiauxins in induction of flowering have thus far been achieved, however, only under photoperiodic conditions near the crictial lengths $(18,79,83)$. The effects of TIBA and DCA in inducing flowering in Xanthium are not specific for these two compounds but extend also to the substituted isobutyric acids which, as shown above, also possess auxin antagonistic activity. Thus, Liverman (83) has found 2,4dichlorophenoxyisobutyric acid to be an effective agent for floral initiation in Xanthium.

It may be noted that the effect of auxin antagonists in inducing flowering in Xanthium is inhibited by applied auxin just as is normal flowering (18). In a complementary fashion, the effect of auxin in inhibiting normal fowering may be suppressed by applied auxin antagonists such as TIBA or DCA [Bonner \& Thurlow (24)].

The relation of TIBA to floral initiation was originally discovered by Zimmerman \& Hitchcock (145) on a photoperiodically indeterminate plant, the tomato. Application of TIBA resulted in the formation of an increased number of flower primordia per cluster, in the induction of terminal flower buds, and, most spectacularly, in the induction of flowering of seedlings. Thus, de Waard \& Roodenburg have shown that in TIBA-treated plants, flower buds may appear after the formation of only 3 leaves instead of after 15 to 19 leaves as is normal for the variety which they used (43). The early findings of Zimmerman \& Hitchcock with the tomato have been confirmed and extended not only by de Waard \& Roodenburg but also by Gorter (59), Zimmerman \& Hitchcock (146), Laibach \& Kribben (73), Osborne \& Wain (95), and others. Osborne \& Wain have also reported that a second substance, $\alpha$-(2-naphthoxy) phenylacetic acid, has an effect on tomato similar to, although less striking than, that exerted by TIBA.

Quantitative effects of TIBA in increasing the numbers of floral primordia which develop on photoperiodically short-day species grown on short days have been noted for soybean by Galston $(48,49)$, for Xanthium [Livermann (83)], and for Kalanchoe [Esteves-de-Sousa (46)] in plants given a minimum induction period. In general, however, application of TIBA to photoperiodically indeterminate species other than tomato and Cucumis have met with negative results [Snyder (104); Tumanov \& Lizandr (125); Whiting \& Murray (140)]. It would seem reasonable, however, to look in to the possibili- 
ties with the indeterminate plants of simulating in some manner the threshold flowering conditions which must obtain with short-day plants before clear flower-inducing effects of TIBA can be demonstrated.

In summary, photoperiodic induction can be inhibited in short-day plants under suitable conditions by application of IAA, NAA, 2,4-D, and other auxins. Flower initiation can be brought about under threshold conditionis by a number of substances including TIBA and other auxin antagonists. These relations suggest an involvement of auxin with the flowering of short-day plants. Information on indeterminate plants, while scattered and incomplete, does, in general, indicate that in these groups also auxins may inhibit flowering and auxin antagonists promote flowering.

This brief review has concerned itself wholly with the auxin relations of flowering as studied by the treatment of the plant with exogenous growth substances. It will be clear that a final and definitive understanding of the part played by auxin in flowering cannot be attained without knowledge of the changes in auxin level which take place in the plant during, for example, photoperiodic induction. It is hard, however, to get satisfactory and convincing information about auxin levels in leaves of photoperiodically sensitive plants because of the presence of inhibitors of the Avena tests in such leaves [Bonner \& Thurlow (24)]. The small amount of information which we do have on the relation of auxin level to photoperiodic regime is however in agreement with the view that leaf auxin levels drop during the night and rise during the day [see summary in (22)].

The pineapple.-The pineapple is remarkable in that the initiation of flowering is elicited by application of minute amounts of such active auxins as NAA or 2,4-D $(36,41,128)$. Larger amounts of these same substances tend to suppress flowering (41). On the other hand, the pineapple normally contains an active auxin, IAA $(56,57,131)$, and flowering, at least as induced by treatment with ethylene, is associated with a decrease in this normal auxin level [Leopold in (129)]. How can these two sets of facts be reconciled? An interesting property of the pineapple brought out by Cooper (41) is its apparent lack of flowering response to applied IAA. Although NAA induced flowering in Cooper's experiments, IAA was ineffective at all concentrations tested. In all of the work on pineapple thus far reported in the literature, synthetic auxins rather than IAA have been used for flower initiation. It appears as a bare possibility, then, that IAA may actually be devoid of flowerinducing properties in the pineapple and may possess only inhibitory effects on the process as it does in certain other species. This would suggest that in the pineapple we may have a species for which NAA and other synthetic materials act as antagonists to the native auxin of the plant. According to this view, NAA, or 2,4-D at appropriately low concentrations would act to block the action of the native IAA, much as TIBA appears to block action of the native auxin in such short-day plants as Xanthium or Kalanchoe. It would be of interest to know whether the flower-inducing action of NAA or 2,4-D on pineapple can be inhibited by the simultaneous application of IAA, just as the action of TIBA on Xanthium can be blocked by added IAA. The. 
hypothesis concerning auxin relations of flowering in the pineapple here proposed is a purely speculative one. Its element of attractiveness lies in the fact that, according to the hypothesis, the auxin relations of flowering in the pineapple would be consistent with those of other plants in so far as we at present understand these relations. Its element of improbability lies in the fact that we have thus far no basis for the view that NAA or 2,4-D may behave as active auxins in one species and as auxin antagonists (at very low concentrations) in other species.

\section{Studies of Auxin Action}

The ability of very small amounts of applied auxin to produce profound changes in treated plants as well as the great diversity of effects which are induced by auxin treatment suggests that auxin may exert its effect on some general and basic metabolic process. According to this view, the observed response, whether growth by elongation, production of roots, suppression of lateral buds or of flowering, increase in rate of protoplasmic streaming, or production of changes in chemical composition would simply be the visible manifestation of the effects of the hormone on this common basic process. This view would suggest that auxin may function as an essential ingredient of some particular enzymatic process central to the plant's economy. A great amount of effort has been devoted to attempts to discover the mechanism by which auxin exerts its action and, in particular, to discover the basic auxin-regulated process which has been envisaged. Among the varied approaches to the subject which have been used, the following are of particular interest:

(a) Studies of the effects of growth substances on individual plant enzyme systems. In such experiments, the auxin may be applied either to the intact tissue prior to isolation of the enzyme or it may be added directly to the reaction mixture with the isolated enzyme.

(b) Determination of the changes in chemical composition of the plant induced by applied auxin.

(c) Studies of the relations between growth and respiration.

(d) Studies of the process of water uptake and the effect of auxins on this process.

We propose to review briefly the general picture developed in each of these lines of inquiry.

\section{Effects of Auxins on Individual Enzyme Systems}

Table II summarizes the information on the effects of auxin on a number of isolated individual plant enzymes or enzyme systems. Most investigations in this field have been concerned with oxidative or other respiratory enzymes. It is clear even from the limited data of Table II that the activities of numerous enzymes are influenced by growth substances added in vitro, some being increased, some inhibited. It is difficult to demonstrate that an effect of auxin on a particular enzyme in vitro bears any intimate relation to 


\section{TABLE II}

Effect of Auxins on Isolated Enzyme Systems*

\begin{tabular}{|c|c|c|c|c|}
\hline Enzyme & Source & Auxin & Effect & Reference \\
\hline Aldolase & pea seed & IAA & $\mathbf{0}$ & Stumpf $1948(110)$ \\
\hline $\begin{array}{l}\text { Alcohol dehy- } \\
\text { drogenase }\end{array}$ & $\begin{array}{l}\text { Avena cole- } \\
\text { optile }\end{array}$ & IAA and NAA & $\mathbf{0}$ & $\begin{array}{l}\text { Berger \& Avery } 1943 \\
\text { (10) }\end{array}$ \\
\hline $\begin{array}{l}\text { Ascorbic acid } \\
\text { oxidase }\end{array}$ & $\begin{array}{l}\text { barley } \\
\text { seedlings }\end{array}$ & $\begin{array}{l}10^{-3} M \text { IAA, IPA, IBA } \\
\text { NAA, } 2,4,5,-T, 2,4-D\end{array}$ & $\begin{array}{l}8 \text { to } 40 \% \text { inhi- } \\
\text { bition }\end{array}$ & 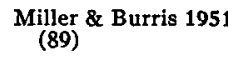 \\
\hline $\begin{array}{l}\text { Ascorbic acid } \\
\text { oxidase }\end{array}$ & bean leaf & $\begin{array}{l}10-2 M 2,4,5-T, M C P A \\
2,4-D, N A \text {, IAA, IPA; } \\
\quad \text { IBA }\end{array}$ & $\begin{array}{l}5 \text { to } 30 \% \text { inhi- } \\
\text { bition }\end{array}$ & $\begin{array}{l}\text { Wagenknecht at al } \\
1951(136)\end{array}$ \\
\hline Catalase & castor bean & $2,4-D$ & $\mathbf{0}$ & Hagen $1949(63)$ \\
\hline Fumarase & $\begin{array}{l}\text { Avena cole- } \\
\text { optile }\end{array}$ & IAA and NAA & $\mathbf{0}$ & $\begin{array}{l}\text { Berger \& Avery } 194 \\
\text { (10) }\end{array}$ \\
\hline $\begin{array}{l}\text { Glutamic de- } \\
\text { hydrogenase }\end{array}$ & $\begin{array}{l}\text { Avena cole- } \\
\text { optile }\end{array}$ & $\begin{array}{l}\text { IAA } 1000 \mathrm{mg} . / \mathrm{I} \\
\text { IBA } 0 \text { to } 100 \mathrm{mg} . / 1 \\
\text { NAA } 1000 \mathrm{mg} . / 1 \\
\text { NAAmide } 0 \text { to } 100 \mathrm{mg} . / 1\end{array}$ & $\begin{array}{l}50 \% \text { inhibition } \\
0 \\
20 \% \text { inhibition } \\
0\end{array}$ & $\begin{array}{l}\text { Berger \& Avery } 1944 \\
(9)\end{array}$ \\
\hline $\begin{array}{l}\text { Glycolic acid } \\
\text { oxidase }\end{array}$ & bean leaf & $\begin{array}{l}5 \times 10^{-4} \text { to } 1 \times 10^{-2} M \\
2,4-D, 2,4,5-T, I A A \\
\text { IPA; IBA, MCPA }\end{array}$ & $\mathbf{0}$ & $\begin{array}{l}\text { Wagenknecht et al } \\
1951(136)\end{array}$ \\
\hline $\begin{array}{l}\text { Glycolic acid } \\
\text { oxidase }\end{array}$ & barley & $\begin{array}{c}10^{-4} M \text { IAA, IPA NAA; } \\
2,4-D, 2,4,5-T, M C P A\end{array}$ & $\begin{array}{l}10 \text { to } 20 \% \text { in. } \\
\text { hibition }\end{array}$ & $\underset{(89)}{\text { Miller \& Burris } 1951}$ \\
\hline IAA oxidase & $\begin{array}{l}\text { pea epico- } \\
\text { tyls }\end{array}$ & $2,4-\mathrm{D} 5 \times 10^{-6}$ to $5 \times 10^{-2} \mathrm{M}$ & stimulation & Goldacre 1949 (54) \\
\hline $\begin{array}{l}\text { Isocitric dehy- } \\
\text { drogenase }\end{array}$ & $\begin{array}{l}\text { Avena cole- } \\
\text { optile }\end{array}$ & $\begin{array}{l}\text { IAA } 0.05 \text { to } 1000 \mathrm{mg} \cdot / 1 \\
\text { IBA and NAA } 0.05 \text { to } 100 \\
\text { mg. } / 1 \text {. } \\
\text { NAAmide } 100 \mathrm{mg} \cdot / 1 . \\
\text { NAAmide } 1000 \mathrm{mg} . / 1 .\end{array}$ & $\begin{array}{c}0 \\
0 \\
30 \% \text { inhibition } \\
50 \% \text { inhibition }\end{array}$ & $\begin{array}{l}\text { Berger \& Avery } 1944 \\
\text { (9) }\end{array}$ \\
\hline $\begin{array}{l}\alpha \text {-hydroxyacid } \\
\text { oxidase }\end{array}$ & $\begin{array}{l}\text { castor bean } \\
\text { seed }\end{array}$ & $2,4-D$ & $\mathbf{0}$ & Hagen 1949 (63) \\
\hline Lipase & $\begin{array}{l}\text { castor bean } \\
\text { seed }\end{array}$ & $1.5 \times 10^{-8} M 2,4-\mathrm{D}$ & $50 \%$ inhibition & Hagen 1949 (63) \\
\hline Lipase & wheat germ & $5.6 \times 10^{-2} M 2,4-\mathrm{D}$ & $50 \%$ inhibition & Kvamme 1949 (72) \\
\hline $\begin{array}{l}\text { Malic dehy- } \\
\text { drogenase }\end{array}$ & $\begin{array}{l}\text { Avena cole- } \\
\text { optile }\end{array}$ & $\begin{array}{l}\text { NAAmide } 1000 \mathrm{mg} . / 1 . \\
\text { IAA } 1000 \mathrm{mg} . / \mathrm{l} . \\
\text { NAA } 1000 \mathrm{mg} . / 1 . \\
\text { IBA } 1000 \mathrm{mg} / \mathrm{l} .\end{array}$ & $\begin{array}{l}\text { inhibition } \\
\text { inhibition } \\
\text { inhibition } \\
\text { inhibition }\end{array}$ & $\begin{array}{l}\text { Berger \& Avery } 194 \\
\quad(10)\end{array}$ \\
\hline $\begin{array}{l}\text { Phosphoglyceric } \\
\text { acid kinase }\end{array}$ & $\begin{array}{l}\text { pea seed } \\
\text { meal }\end{array}$ & IAA $10^{-2} M$ & $\mathbf{0}$ & $\begin{array}{l}\text { Axelrod \& Bandur } \\
\text { 8ki (unpublished) }\end{array}$ \\
\hline $\begin{array}{l}\text { Phosphohexo- } \\
\text { kinase }\end{array}$ & $\begin{array}{c}\text { pea seed } \\
\text { meal }\end{array}$ & IAA $5 \mathrm{mg} . / 1$. & $\mathbf{0}$ & $\begin{array}{l}\text { Axelrod, Saltman, } \\
\text { Bandurski \& Ba } \\
\text { ker (unpublished) }\end{array}$ \\
\hline $\begin{array}{l}\text { Polyphenol } \\
\text { oxidase }\end{array}$ & $\begin{array}{l}\text { castor bean } \\
\text { seed }\end{array}$ & $2,4-D$ & $\mathbf{0}$ & Hagen $1949(63)$ \\
\hline $\begin{array}{l}\text { Glycolic acid } \\
\text { oxidase }\end{array}$ & barley & $\begin{array}{c}10^{-4} M \text {, IAA, IPA, NAA; } \\
2,4-\mathrm{D}, 2,4,5-\mathrm{T}, \mathrm{MCPA}\end{array}$ & $\begin{array}{c}10 \text { to } 20 \% \text { in- } \\
\text { hibition }\end{array}$ & $\begin{array}{l}\text { Miller \& Burris } 1951 \\
(89)\end{array}$ \\
\hline
\end{tabular}

* Abbreviations:

IAA-Indoleacetic acid

IBA-Indole butyric acid

NAA- $\alpha$-napthaleneacetic acid NAAmide $-\alpha$-napthaleneacetimide
2,4-D-2,4-dichlorophenoxyacetic acid

IPA-Indolepropionic acid

2,4,5-T-trichlorophenoxyacetic acid

MCPA-2-methyl-4-chlorophenoxyacetic acid

the effects of auxin in eliciting physiological responses. To establish such a relationship, one might (a) demonstrate similar requirements as to structural specificity, (b) correlate the sensitivity of the enzyme to auxin with the 
sensitivity to auxin of the species from which the enzyme is extracted, and (c) show that effects on the enzymic reaction occur over the same range of auxin concentrations which influence plant growth and similar physiological responses. It has not been shown for any of the cases reported in Table II that these criteria are fulfilled and we do not know, therefore, that any of the effects in Table II are of physiological interest.

Treatment of plant tissue with auxin has resulted in several interesting effects upon the activities of the subsequently extracted enzymes. The first such effect to be reported was that of Berger \& Avery (11) on the alcohol and malic dehydrogenases of Avena coleoptile tissue. Increases in activity of the order of 200 and 150 per cent, respectively, were obtained. These effects develop much more slowly than the growth response and are presumably secondary to it. No effects were found under the same conditions on glutamic, citric, or isocitric dehydrogenase. Gall (47) observed that bean stem sections cultured on starch-agar in the presence of 2,4-D degrade the starch contained in the media over a considerably greater area than untreated sections. Presumably the 2,4-D-treated, and, therefore, growing tissue possesses greater soluble amylase or phosphorylase activity than does the control tissue. Alternatively, the permeability of the cell membranes to these enzymes might be increased. Newcomb (93) has obtained large increases in the ascorbic acid oxidase activity (fresh weight basis) of a particulate fraction isolated from tobacco pith sections as a result of culturing the sections in the presence of $3.5 \mathrm{mg}$./1. IAA. The increase precedes the growth and respiratory changes induced by the growth substance treatment. The author therefore suggests that ascorbic acid oxidase activity may be causally related to growth. It is of interest that neither cytochrome oxidase nor tyrosinase showed any marked response to the auxin treatment.

Galston (52) has reported a marked diminution of the catalase content of Helianthus tuberosus tissue as a result of culture in the presence of 2,4-D or IAA. Further, normal tissues of Scorzonera, Vitis, and Parthenocissus contained more catalase than did habituated tissues which, in turn, contained more catalase than did crown gall tissue. There was thus an inverse correlation between the growth of the tissue and the content of catalase. Olsen (94) has shown that the phosphatase activity of $Z e a$ roots increases strikingly as a result of culture in 1.5 p.p.m. 2,4-D solution, a concentration which also causes an inhibition of root growth. The effects were apparent in as short a time as $3 \mathrm{hr}$.

It is clear, then, that treatment of plant tissues with auxin results in effects on a wide variety of enzymes; the activities of some are increased while the activities of others are decreased. It is, however, difficult to assess the physiological significance of such effects since in most cases a comparison is being made between growing and nongrowing tissue. It is not clear that there is any direct relation between these effects and the mechanism of auxin action. Aside from this, however, the results are valuable in so far as they serve to more rigorously define growth and to give us a more detailed description of the chemical changes which occur during this process. 


\section{Auxin-Induced Changes in Plant Composition}

Changes in chemical composition of the plant, induced by application of herbicidal concentrations of growth-regulating substances, have recently been reviewed by Mitchell (90) and by Blackman et al. (12) and will not be reviewed here. Investigations of changes in chemical composition which attend the induction of growth by auxin, a subject much studied in the past, have recently been intensified by Christiansen \& Thimann and by Burström. The experiments of Christiansen \& Thimann were intended as an all-out effort to follow every chemical change which occurs in plant tissue during the response to growth substance. A portion of this work has been reviewed by Thimann, Bonner \& Christiansen (122) and by Thimann (116). Their experimental material consisted of $20 \mathrm{~mm}$. pea stem sections incubated for $24 \mathrm{hr}$. in water or IAA at $1 \mathrm{mg}$./1. The control sections incubated in water increase in length by 20 per cent and in fresh weight by 22 per cent as contrasted to a 50 per cent increase in length and 60 per cent increase in fresh weight for the auxin-treated sections [Christiansen \& Thimann (32)]. Both treated and control sections lose approximately 11 per cent of their initial dry weight. The auxin-treated sections respire 15 to 30 per cent faster (dry weight basis) than the control sections. About 25 per cent of the reducing sugars initially present are consumed both by the control and auxin-treated sections. Over 70 per cent of the sucrose initially present is consumed by the auxin-treated sections, while only $\mathbf{5 7}$ per cent is lost by the controls. Starch and dextrins are not present in analytically detectable amounts in the pea tissue. No changes were found in the organic phosphorous fraction as a whole. The methods used did not, however, differentiate between the individual constituents of the organic phosphorous fraction. A slight increase in cell wall constituents occurs during growth. Polysaccharides and polyuronides compose up to 23 per cent of the initial dry weight. This increases to 27 per cent for the auxin-treated sections and to 25 per cent for the control sections. There appears to be a slightly greater consumption of organic acids and of fats in the treated sections [Christiansen \& Thimann (33)]. Slightly more of the amino acids initially present are consumed [Christiansen \& Thimann (34)] and slightly more protein synthesized by treated than by untreated sections. Christiansen $\&$ Thimann conclude that these transformations of nitrogenous substances are of critical significance for growth.

Studies by Boroughs (27) and by Burström (31), in contrast to those of Christiansen \& Thimann, have failed to find any direct relation of protein synthesis to growth. Boroughs, in an elegant study, followed the influence of auxin on the rate of protein turnover in corn coleoptile sections as determined by the rate of incorporation of $\mathrm{C}^{14}$-labeled glycine and leucine into the plant proteins. The coleoptiles were incubated in media containing 3 per cent sucrose $(0.03 \mathrm{M}), \mathrm{K}$ maleate $(\mathrm{pH} 4.6)$, the carboxyl-labeled amino acid $(0.002 \mathrm{M})$, and with or without $3 \mathrm{mg} . / 1$. IAA. Growth, total protein, and specific activity of protein were measured at intervals up to $24 \mathrm{hr}$. No appreciable net synthesis of protein occurred either in the presence or absence 
of IAA. The rate at which the radioactivity initially supplied in the form of amino acids appeared in the protein of the sections was similarly independent of the presence or absence of growth substance. Auxin did not therefore alter the rate of protein synthesis, nor did it influence the turnover rate of the protein. In the work of Burström (31), the growth of wheat roots was follower in the presence or absence of $p$-chlorophenoxyisobutyric acid (PCIB). Treatment with this auxin antagonist resulted, for example, in an 88 per cent increase in length (in $10^{-6} \mathrm{M}$ PCIB) with only an 8 per cent increase in protein nitrogen. From the lack of proportionality between growth and protein synthesis, Burström concludes that the processes are not intimately linked.

In summary, the chemical changes associated with auxin-induced growth are small. This applies, for example, to the changes in organic acids, amino acids, carbohydrates, and total dry weight. It had previously been shown that an increase in cell wall constituents is not an obligatory accompaniment of growth [Bonner (14)]. The absence of protein synthesis during section growth observed by Boroughs (27) and the lack of proportionality of protein synthesis and growth observed by Christiansen \& Thimann (34) and by Burström (31) would further indicate that protein synthesis is not a necessary accompaniment of growth. Thus, from a quantitative standpoint, there is but one striking chemical effect of auxin treatment which is common to all the experiments described above. This is the effect of auxin upon the uptake of water by the tissue. So far as the experiments reviewed are concerned, the only meaningful metabolic difference between a growing and a nongrowing section would appear to be the uptake of water by the growing section.

\section{RESPIRATION AND GROWTH}

Much of the work on the mechanism of auxin action has involved attempts to elucidate the nature of the connection between respiration and auxin-induced growth responses. Several recent reviews have considered this relationship [Audus (4); Avery (5); Bonner \& Wildman (26); and Thimann (116)]. That growth in response to auxin is in fact obligatorily coupled to oxidative metabolism has been known for many years [Bonner (13)]. There remain, however, a number of questions concerning the nature of the energetic coupling - questions which are common to animal and plant physiology. Two experimental approaches to the study of the linkage between respiration and growth have been utilized. The characteristics of the auxin-induced increase in respiration may be studied, or the effects of varied respiratory inhibitors on growth may be investigated in an attempt to determine the point of auxin action.

That the same range of concentrations of auxin which effect growth may also increase respiration is well established [Berger \& Avery (8); Bonner (17); Christiansen \& Thimann (33); Commoner \& Thimann (40); Michel (86)]. It is also true, however, that increased respiration does not necessarily accompany the auxin-induced growth response [Bonner (15)]. There is there- 
fore no constant and uniform stoichiometry between auxin supply and respiration.

In theory it should be possible to discover how auxin increases the respiratory rate by finding out first what is the rate-limiting factor in the absence of auxin. This limiting factor does not appear to be either the substrate concentration or the capacity of the respiratory enzyme system (25). Of particular interest in this connection are the studies of the effect of auxin on the isolated mitochondrial respiratory system. By appropriate procedures, it is possible to separate from plant tissues an enzyme complex, associated with the mitochondria, which is capable of oxidizing pyruvate to $\mathrm{CO}_{2}$ and water [Millerd et al. (88)]. These isolated particles are capable of accounting for the bulk of the respiration of the stems of seedlings such as mung bean [Millerd (87)]. The rate at which pyruvate is oxidized in vitro by the isolated mitochondrial system is not influenced by added auxin [Price, Bonner \& Millerd (96)] nor is the capacity of the mitochondria for pyruvate oxidation influenced by pretreatment of the living plant with IAA. The failure to obtain increased respiration with the isolated system is by no means conclusive evidence that auxin does not act in this portion of the metabolism. It is, however, in agreement with other evidence which suggests that the respiration-limiting and auxin-influenced step in seedling tissues, such as those of the Avena coleoptile, is concerned with the phosphate transfer mechanism.

A second approach to the study of the relation between auxin-induced growth and respiration is based upon the experimental disassociation of the two processes by the use of inhibitors. Thus, certain substances inhibit growth and respiration to the same extent. This is true of cyanide $(13,15)$. It would appear then that the electron transfer portion of respiration is essential to growth and that inhibition of this electron transfer results in proportional growth inhibition. Other inhibitors selectively influence growth, leaving respiration unaffected or affected only to a lesser extent. Thus, for example, arsenate at a concentration of $30 \mathrm{mg}$. $/ 1$. inhibits growth by 94 per cent while respiration continues unaffected (20) Canavanine at a concentration of $50 \mathrm{mg}$./1. is not inhibitory to endogenous respiration but inhibits the increase in respiration elicited by IAA (16) and inhibits growth by 90 per cent (17). Fluoride is also a selective inhibitor of growth [Bonner $\&$ Wildman (26); Christiansen \& Thimann (33)]. Similarly, Christiansen \& Thimann (33) have shown that concentrations of iodoacetate and of arsenite sufficient to inhibit growth 50 per cent, inhibit respiration to the extent of 31 and 19 per cent, respectively. There are no known inhibitors which inhibit respiration without inhibiting growth. We must-conclude that there are steps in the auxin-induced growth process and, indeed, in the mechanism by which auxin increases the respiratory rate, which are more sensitive to certain inhibitors than is respiratory gas exchange. This again suggests the conclusion arrived at earlier in this section that the effect of auxin is not directly concerned with either the electron transfers or carbon transformations of respiration. 
A deeper insight into the relationship between growth and respiration has been obtained by the use of the inhibitor 2,4-dinitrophenol (DNP). This substance may inhibit growth almost completely while causing an actual in. crease in the rate of respiration. Thus, for example, a concentration of $5 \mathrm{mg}$. /1. DNP will inhibit growth by 88 per cent while actually increasing respiration by 38 per cent [Bonner (16)]. A similar stimulation of respiration with DNP has been observed by Kelly (70). We have sufficient knowledge of the action of DNP on plants to make possible an interpretation of the effects of DNP on growth and respiration. DNP is known to inhibit the synthesis of adenosine triphosphate (ATP) which is normally coupled to the respiratory oxidations. In tissues in which the capacity of the phosphorylating system limits respiratory rate, this rate is actually increased by uncoupling with DNP [Loomis \& Lipmann (85)]. Reactions which are driven by ATP and which are dependent upon respiration for this ATP are, however, inhibited. Among the many well-established examples of energy-requiring processes which are inhibited by DNP are enzyme synthesis [Sussman \& Spiegleman (111)], $\mathrm{HCl}$ secretion by oxyntic cells [Davies (42)], and cell division [Clowes \& Krahl (37)]. Auxin-induced growth is not the only plant process which is known to be inhibited by DNP. Robertson (102) found that concentrations of DNP which inhibit active salt uptake by roots stimulate oxygen uptake. A similar observation was made by Stenlid (108) for the absorption of glucose by wheat roots, while Hackett \& Thimann (62) found that DNP inhibits water uptake by potato discs. Recent work on oxidative phosphorylation and the synthesis of ATP by plants has shown that energetic coupling in the plant is much as it is in animals. The respiratory oxidations of isolated plant mitochondria are linked to the uptake of ortho phosphate and the synthesis of ATP [Millerd (87); Millerd et al. (88)]. The synthesis of ATP by plant mitochondria is inhibited by DNP [Bonner \& Millerd (23)]. It would, therefore, appear that the inhibition of growth by DNP may be explained by the necessity of ATP for growth. Since auxin exerts no effect on respiration in the presence of DNP, arsenate, or other uncoupling agents, it follows that the influence of auxin on respiration is exerted through that part of the system which is uncoupled and hence inactive in the presence of such agents.

How then may we picture the mechanism by which auxin increases the respiratory rate? It would appear that the rate of respiration of the Avena coleoptile, for example, is normally limited by the capacity of the phosphorylating system. This is indicated not only by the fact that uncoupling with DNP increases the rate of respiration but also by the fact that the addition of adenylic acid to the plant increases the respiratory rate (17). Since auxin increases respiration in a system whose rate limiting step is the phosphorylating one, it appears logical to conclude that auxin must in some manner affect this phosphorylative process.

The evidence which has been presented indicates that, at least under the conditions of short-term section experiments, the relationship between respiration and growth may consist in a dependency of the growth process upon 
the ATP produced in respiration. What then is the nature of this ATP-requiring growth process?

\section{WATER UPTAKE}

Considerations presented in an earlier section have indicated that, of all the chemical changes during auxin-induced growth, the most spectacular is that concerned with water uptake. We have further seen that at least in the case of growth by elongation, the dependency of growth upon respiration seems to lie in a requirement of growth for ATP. It will be of interest to consider the possibility that water uptake may be the respiration- and ATPrequiring process of auxin-induced growth. Since there is no large and consistent effect of auxin in increasing respiration, it would appear necessary to assume that the effect of auxin would be either directly on the process of water uptake or upon the linkage of ATP to this process.

That auxin does influence water uptake by plant tissue has been recognized since the early work of Reinders $(99,100)$, of Commoner et al. $(38,39)$, and of Van Overbeek (127), all of which were concerned with the role of auxin in water uptake by potato tuber discs. That the effect is a result of an active secretion of water into the cell interior was indicated by Commoner $\&$ co-workers (38) who found that auxin can induce water uptake in discs immersed in plasmolyzing concentrations of sucrose. Commoner \& Mazia (39) further found that auxin stimulates the uptake of $\mathrm{KCl}$ and in the same range of concentrations which increase water uptake. They concluded that auxin brings about an active water uptake and does so by increasing the absorption of osmotically active substances such as salts. Van Overbeek (127) has, however, shown that the osmotic concentration of the cell contents as measured cryoscopically actually decreases during response to auxin. This fact, together with the observation of Reinders (100) that auxin effects can be obtained even with tissues immersed in essentially pure water, caused Van Overbeek to conclude that the effect of auxin on water uptake must be exerted through some mechanism other than an osmotic one-presumably by active water secretion.

That such active water uptake, whose existence was early suggested by experiments of Bennet-Clark et al. (6), may depend intimately on respiration has been shown by Steward et al. (109), who found a reasonably direct relationship between the water uptake and the respiration rate of potato discs. Reinders $(99,100)$ made similar observations with potato tuber discs and discs of other storage tissues. Van Overbeek (126) showed that 50 to 70 per cent of the root pressure of decapitated tomato plants apparently results from an active uptake of water, which is respiration-dependent and cyanideinhibitable.

There is thus a considerable body of evidence indicating the existence of a metabolically controlled and dependent water uptake. In order to take up water against a gradient, metabolic energy must be expended by the cell. Levitt (78) has calculated that an appreciable gradient in water concentra- 
tion across the cell boundary may be maintained by the energy liberated in respiration. That water uptake is inhibited by DNP has been shown not only for the case of auxin-controlled growth in length but also for the case of auxin-induced water uptake by potato discs [Hackett \& Thimann (62)]. This suggests that active water uptake, in so far as it takes place, may be powered in some way by ATP. The process of water uptake by sections and by discs of storage tissue is increased by auxin and it appears that salt uptake may be similarly influenced [Commoner (39)]. We have seen that the analytically detectable effect of auxin on metabolites other than water are slight indeed. Our attention has thus been directed to the possibility that auxin may serve to couple respiration to the process of water accumulation. The study of whether this is indeed the primary effect of auxin will undoubtedly provide a profitable field for future investigation.

\section{LITERATURE CITED}

1. Aberg, B., Physiol. Plantarum, 3, 447 (1950)

2. Ashby, W. C., Botan. Gaz., 112, 237 (1951)

3. Atkinson, D., Frasch Foundation Ann. Rept. (Calif. Inst. Technol., Pasadena, Calif., 50 pp., 1950)

4. Audus, L. J., Biol. Revs., Cambridge Phil. Soc., 24, 51 (1949)

5. Avery, G. S., Jr., Plant Growth Substances, 105 (Univ. of Wis. Press, Madison, Wis., 476 pp., 1951)

6. Bennett-Clark, J. A., Greenwood, A. D., and Barker, J. W., New Phytologist, 35, 277 (1936)

7. Bentley, J. A., Nature, 165, 449 (1950)

8. Berger, J., Smith P., and Avery, G. S., Am. J. Botany, 33, 601 (1946)

9. Berger, J., and Avery, G. S., Am. J. Botany, 31, 11 (1944)

10. Berger, J., and Avery, G. S., Am. J. Botany, 30, 297 (1943)

11. Berger, J., and Avery, G. S., Science, 98, 454 (1943)

12. Blackman, G. E., Templeman, W. G., and Halliday, D. J., Ann. Rev. Plant Physiol., 2, 199 (1950)

13. Bonner, J., J. Gen. Physiol., 17, 63 (1933)

14. Bonner, J., Proc. Natl. Acad. Sci., 20, 393 (1934)

15. Bonner, J., J. Gen. Physiol., 20, 1 (1936)

16. Bonner, J., Am. J. Botany, 36, 323 (1949)

17. Bonner, J., Am. J. Botany, 36, 429 (1949)

18. Bonner, J., Botan. Gaz., 110, 625 (1949)

19. Bonner, J. (Unpublished data)

20. Bonner, J., Plant Physiol., 25, 181 (1950)

21. Bonner, J., and Galston, A. W., Botan. Gaz., 106, 185 (1944)

22. Bonner, J., and Liverman, J., Growth and Differentiation in Plants (Am. Soc. Plant Physiol. Monograph in press)

23. Bonner, J., and Millerd, A. (Unpublished data)

24. Bonner, J., and Thurlow, J., Botan. Gaz., 110, 613 (1949)

25. Bonner, J., and Wildman, S. G., Arch. Biochem., 10, 497 (1946)

26. Bonner, J., and Wildman, S.'G., Growth, 10 (Suppl.), 51 (1946)

27. Boroughs, H., Paper presented to Am. Soc. Plant Physiol. (Western Section), (Los Angeles, 1951) 
28. Bourne, M. C., and Young, L., Biochem. J., 28, 805 (1934)

29. Burström, H., Physiol. Plantarum, 3, 277 (1950)

30. Burström, H., Physiol. Plantarum, 4, 470 (1951)

31. Burström, H., Physiol. Plantarum, 4, 199 (1951)

32. Christiansen, G. S., and Thimann, K. V., Arch. Biochem., 26, 230 (1950)

33. Christiansen, G. S., and Thimann, K. V., Arch. Biochem., 26, 248 (1950)

34. Christiansen, G. S., and Thimann, K. V., Arch. Biochem., 28, 117 (1950)

35. Cholodny, N. G., Herbage Revs., 7, 223 (1939)

36. Clark, H., and Kearns, K., Science, 95, 536 (1942)

37. Clowes, G. H. A., and Krahl, M. E., J. Gen. Physiol., 20, 145 (1936)

38. Commoner, B., Fogel, S., and Muller, W. H., Am. J. Botany, 30, 23 (1943)

39. Commoner, B., and Mazia, D., Plant Physiol, 17, 682 (1942)

40. Commoner, B., and Thimann, K. V., J. Gen. Physiol., 24, 279 (1941)

41. Cooper, W. C., Proc. Am. Soc. Hort. Sci., 41, 93 (1942)

42. Davis, R. E., Biol. Revs. Cambridge Phil. Soc., 26, 87 (1951)

43. de Waard, J., and Roodenburg, J. W. M., Proc. Koninkl. Nederland. Akad. Wetanschap., 51, 248 (1948)

44. de Waard, J., and Florschütz, P. A., Proc. Koninkl. Nederland. Akad. Wetanschap., 51, 1317 (1948)

45. Dostal, R., and Hosek, M., Flora, 131, 263 (1937)

46. Esteves-de-Sousa, A., Portuguesa Acta Biolog., 3, 91 (1950)

47. Gall, H. J. F., Botan. Gaz., 110, 319 (1948)

48. Galston, A. W., The Physiology of Flowering with Special Reference to Floral Initiation in Soybeans (Doctoral thesis, Univ. of Illinois, Urbana, Ill., 1943)

49. Galston, A. W., Am. J. Botany, 34, 356 (1947)

50. Galston, A. W., Am. J. Botany, 34, 356 (1947)

51. Galston, A. W., Science, 111, 619 (1950)

52. Galston, A. W., Compt. rend., 232, 1505 (1951)

53. Galston, A. W., ànd Baker, R. S., Am. J. Botany, 38, 190 (1951)

54. Goldacre, P. L., Australian J. Sci. Research, [B]2, 154 (1949)

55. Goldstein, A., J. Gen. Physiol., 27, 529 (1944)

56. Gordon, S. A., and Sanchez-Nieva, F., Arch. Biochem., 20, 356 (1949)

57. Gordon, S. A., and Sanchez-Nieva, F., Arch. Biochem., 20, 367 (1949)

58. Gordon, S. A., and Weber, R. P., Plant Physiol., 26, 192 (1951)

59. Gorter, C., Proc. Koninkl. Nederland. Akad. Wetenschap., 52, 1185 (1949)

60. Green, M., and Fuller, H., Science, 108, 415 (1948)

61. Haagen-Smit, A. J., Dandliker, W. B., Wittwer, S. H., and Murneek, A. E., Am. J. Botany, 33, 118 (1946)

62. Hackett, D., and Thimann, K. V., Plant Physiol., 25, 648 (1950)

63. Hagen, C. E., Clagett, C. O., and Helgeson, E. A., Science, 110, 116 (1949)

64. Holley, R. W., Boyle, F. P., Durfee, H. K., and Halley, A. D., Arch. Biochem., 32, 192 (1951)

65. Hamner, K. C., and Bonner, J., Botan. Gaz., 100, 388 (1938)

66. Hansch, C., and Muir, R. M., Plant Physiol., 25, 389 (1950)

67. Hansch, C., Muir, R. M., and Metzenberg, R. L., Plant Physiol., 26, 812 (1951)

68. Harder, R., and van Senden, H., Naturwissenschaften, 36, 348 (1949)

69. Hitchcock, A. E., and Zimmerman, P. W., Contrib. Boyce Thompson Inst., 16, 225 (1951)

70. Kelly, S., and Avery, Gr. S., Jr., Am. J. Botany, 36, 421 (1949) 
71. Koepfli, J. B., Thimann, K. V., and Went, F. W., J. Biol. Chem., 122, 763 (1937)

72. Kvamme, J., Clagett, C. O., and Treumann, B., Arch. Biochem., 24, 321 (1949)

73. Laibach, F., and Kribben, F., Naturwissenschaften, 37, 114 (1950)

74. Larsen, P., Dansk Botan. Arkiv, 11, 1 (1944)

75. Larsen, P., Am. J. Botany, 36, 32 (1949)

76. Larsen, P., Plant Physiol., 26, 697 (1951)

77. Leopold, C., and Thimann, K. V., Am. J. Botany, 36, 342 (1949)

78. Levitt, J., Plant Physiol., 23, 505 (1948)

79. Li, C. H., Inhibition and Induction of Flowering in Higher Plants by Application of Auxins and Other Substances (Master's thesis, Calif. Inst. Technol., Pasadena, Calif., 1949)

80. Lineweaver, H., and Burk, D., J. Am. Chem. Soc., 56, 658 (1934)

81. Link, G. K. K., Egger, S. V., and Moulton, J., Botan. Gaz., 101, 928 (1940)

82. Linser, H., Planta, 39, 377 (1951)

83. Liverman, J., Paper, presented to Am. Soc. Plant Physiol. (Los Angeles, 1951)

84. Lona, F., Rend. inst. lombardo di scienze, 83, 1 (1950)

85. Loomis, W. F., and Lipmann, F., J. Biol. Chem., 173, 807 (1948)

86. Michel, B. E., Botan. Gaz., 112, 418 (1951)

87. Millerd, A., Respiratory Oxidation and Energy Transfer by Plant Systems (Doctoral thesis, Calif. Inst. Technol., Pasadena, Calif., and Univ. of Sydney, Sydney, Australia, 1951)

88. Millerd, A., Bonner, J., Axelrod, B., and Bandurski, R., Proc. Natl. Acad. Sci., 37, 855 (1951)

89. Miller, I. H., and Burris, R. H., Am. J. Botany, 38, 547 (1951)

90. Mitchell, J. W., Plant Growth Substances, 141 (Univ. of Wis. Press, Madison, Wis., 476 pp., 1951)

91. Muir, R. M., and Hansch, C., Plant Physiol., 26, 369 (1951)

92. Muir, R. M., Hansch, C., and Gallup, A. H., Plant Physiol., 24, 359 (1949)

93. Newcomb, Eldon H., Proc. Soc. Exptl. Biol. Med., 76, 504 (1951)

94. Olsen, K., Paper presented to Am. Soc. Plant Physiol. (Western Section), (Salt Lake City, 1950)

95. Osborne, D. J., and Wain, R. L., J. Hort. Sci., 26, 60 (1950)

96. Price, C., Bonner, J., and Millerd, A. (Unpublished data)

97. Quastel, J. H., Biochem. J., 20, 166 (1926)

98. Redemann, C. T., Wittwer, S. H., and Sell, H. M., Arch. Biochem. Biophys., 32, 80 (1951)

99. Reinders, D. E., Proc. Kon. Akad. V. Wetenschap. Amsterdam, 41, 820 (1938)

100. Reinders, D. E., Rec. trav. botan. neerland., 39, 1 (1942)

101. Reinert, J., Z. Naturforsch, 56, 374 (1950)

102. Robertson, R. N., Ann. Rev. Plant Physiol., 2, 1 (1951)

103. Skoog, R., Schneider, C., and Malan, P., Am. J. Botany, 29, 568 (1942)

104. Snyder, W. E., Plant Physiol., 24, 195 (1949)

105. Strauss, O. H., and Goldstein, A., J. Gen. Physiol., 26, 259 (1943)

106. Stehsel, M. (Unpublished data)

107. Stehsel, M., and Wildman, S. G., Abstracts Ann. Meeting, Botan. Soc. Am. (Physiol. Section), (Columbus, Ohio, 1950)

108. Stenlid, G., Physiol. Plantarum, 2, 350 (1949)

109. Steward, F. C., Stout, P. R., and Preston, C., Plant Physiol., 15, 409 (1940)

110. Stumpf, P. K., J. Biol. Chem., 176, 233 (1948) 
111. Sussman, M., and Spiegelman, S., Arch. Biochem., 29, 85 (1950)

112. Synerholm, M. E., and Zimmerman, P. W., Contrib. Boyce Thompson Inst. 14, 91 (1945)

113. Tang, Y. W., and Bonner, J., Arch. Biochem., 13, 11 (1947)

114. Tang, Y. W., and Bonner, J., Am. J. Botany, 35, 570 (1948)

115. Teas, H. J., and Newton, A., Plant Physiol., 26, 494 (1951)

116. Thimann, K. V., Growth, 15 (In press)

117. Thimann, K. V., Plant Growth Substances, 21 (Univ. of Wis. Press, Madison, Wis., 476 pp., 1951)

118. Thimann; K. V., and Bonner, W. D., Jr., Am. J. Botany, 35, 271 (1948)

119. Thimann, K. V., and Bonner, W. D., Jr., Plant Physiol., 23, 158 (1948)

120. Thimann, K. V., and Bonner, W. D., Jr., Am. J. Botany, 36, 214 (1949)

121. Thimann, K. V., and Bonner, W. D., Jr., Proc. Natl. Acad. Sci., 35, 272 (1949)

122. Thimann, K. V., Bonner, W. D., Jr., and Christiansen, G. S., Plant Growth Substances, 97 (Univ. of Wis. Press, Madison, Wis., 476 pp., 1951)

123. Thompson, H. E., Swanson, C. P., and Norman, A. G., Botan. Gaz., 107, 476 (1946)

124. Thurlow, J., and Bonner, J., Am. J. Botany, 34, 603 (1947)

125. Tumanov, I. I., and Lizandr, A. A., J. botan. U.R.S.S., 31, 20 (1946)

126. van Overbeek, J. Am. J. Botany, 29, 677 (1942)

127. van Overbeek, J., Am. J. Botany, 31, 265 (1944)

128. van Overbeek, J., Science, 102, 621 (1945)

129. van Overbeek, J., Plant Growth Substances, 225 (Univ. of Wis. Press, Madison, Wis., 476 pp., 1951)

130. van Overbeek, J., Blondeau, R., and Horne, V., Am. J. Botany, 38, 589 (1951)

131. van Overbeek, J., Gregory, L. E., and Velez, I., Proc. Am. Soc. Hort. Sci., 47, 434 (1946)

132. Veldstra, H., and Havinga, E., Rec. trav. chim., 62, 841 (1943)

133. Veldstra, H., and Havinga, E., Enzymologia, 11, 373 (1945)

134. von Denffer, D., and Gründler, H., Biol. Zentr., 69, 272 (1950)

135. Wagenknecht, A. C., and Burris, R. H., Arch. Biochem., 25, 30 (1950)

136. Wagenknecht, A. C., Riker, A. J., Allen, T. C., and Burris, R. H., Am. J. Botany, 38, 550 (1951)

137. Weintraub, R. L., and Norman, A. G., Econ. Botany, 3, 289 (1949)

138. Went, F. W., Rec. trav. botan. néerland., 25, 1 (1928)

139. Went, F. W., Arch. Biochem., 20, 131 (1949)

140. Whiting, A. G., and Murray, M. A., Botan. Gaz., 109, 447 (1948)

141. Wildman, S. G., and Bonner, J., Am. J. Bot., 35, 740 (1948)

142. Wildman, S. G., Ferri, M., and Bonner, J., Am. J. Botany, 33, 23 (1946)

143. Wilske, C., and Burström, H., Physiol. Plantarum, 3, 58 (1950)

144. Zimmerman, P. W., Torreya, 43, 89 (1943)

145. Zimmerman, P. W., and Hitchcock, A. E., Contrib. Boyce Thompson Inst., 12, 491 (1942)

146. Zimmerman, P. W., and Hitchcock, A. E., Contrib. Boyce Thompson Inst., 15, $353(1949)$

147. Zimmerman, P. W., and Hitchcock, A. E., Contrib. Boyce Thompson, Inst., 16,209 (1951) 


\section{CONTENTS}

PAGE

Factors Affecting Availability of Inorganic Nutrients in Solls With Special Reference to Micro-Nutrient Metals, $G$. $W$. Leeper . . . . . . . . . . . . . . . . . 1

Glycolytic Enzymes in Higher Plants, $P . K$. Stumpf . . . $~ 17$

Metabolism of Phosphorylated Compounds in Plants, $H$. Albaum 35

Studies of the Physiology, Pharmacology, and Biochemistry of THE Auxins, J. Bonner and R. S. Bandurski . . . . . . 59

Agricultural Application of Growth Regulators and their Physiological Basis, J. van Overbeek . . . . . . . . . . .87

Transport of Organic Compounds, W. H. Arisz . . . . . . . . 109

Leaf Proteins, S. Wildman and A. Jagendorf . . . . . . . 131

Physiological Aspects of Low Temperature Preservation of Plant Products, M. A. Joslyn and H. C. Diehl . . . . . 149

Physiology of Virus Diseases, F. C. Bawden and N. W. Pirie . . 171

Mechanisms of Ion Absorption by Roots, R. Overstreet and L. Jacobson . . . . . . . . . . . . . . . . . . 189

Physiological Bases for Assessing the Nutritional RequireMents of Plants, A. Ulrich . . . . . . . . . . . . . . . 207

Photosynthesis, E. Rabinowitch . . . . . . . . . . . . . . . . $\quad .229$

Physiology of Flowering, A. Lang . . . . . . . . . . 265

Carboxylating Enzymes in Plants, B. Vennesland and E. E. Conn 307

Tree Physiology, B. Huber . . . . . . . . . . . . . . . 333

INDEXES . . . . . . . . . . . . . . . . . . 347 